\title{
EFFECT OF RIBOFLAVIN OR IRON DEFICIENCY ON THE CELL RENEWAL RATE OF INTESTINAL MUCOSA
}

\author{
KAZUMA MIYAJI ${ }^{2}$ AND YASUHIRO HARA ${ }^{1}$ \\ Department of Internal Medicine, School of Medicine \\ Kyushu University, Fukuoka
}

(Received December 1, 1965)

Riboflavin deficiency is well known to cause characteristic clinical symptoms of the tongue and skin since the report of Sebrell and Butler (1). However, the reason why such symptoms occur chiefly on the mucous membrane and skin has not yet been elucidated. The mucous membrane and skin are the special tissues in which the cells are always reproduced by division and proliferation on the one hand and removed by exfoliation and desquamation on the other hand. Taking the fact in mind, cell renewal rate is assumed to play a significant role in manifestation of these symptoms, but such a study has not yet been done. The authors have therefore investigated the effects of riboflavin deficiency on the regeneration rate of the epitheliar cells of the mucous membrane of the small intestine in which the cells are most actively renewed among the tissues of the whole body.

In the deficiency of niacin (3), vitamin $\mathrm{B}_{12}$ (4) or iron, each characteristic symptoms are detectable on the mucous membrane. In the last case (5-9), atrophies of the tongue papillae, of the mucous membranes of the larynx and oesophagus and atrophic gastritis are accompanied with anemia, suggesting the lowering of the epitheliar cell renewal rate in these mucous membranes. The effect of riboflavin deficiency on the renewal rate was therefore compared with that of iron deficiency.

\section{EXPERIMENTAL}

On the basis of $\mathrm{P}^{32}$ incorporation into nuclear DNA of the epitheliar cells of the small intestine in riboflavin deficient, iron deficient and normal rats, the effect of each deficiency on the cell renewal rate was examined.

The rate of cell renewal is affected by nutritional state (10), age of rats (11), and hormone action (12). Therefore, Wistar-King A strain male rats were used and the control animals were adjusted carefully to keep the same body weight as the dificient ones.

\section{Deficient Rats}

The rats were divided into four experimental groups: (a) acute riboflavin

1 宮地一馬, 原 泰寬.

${ }^{2}$ Present address: Department of Internal Medicine, School of Medicine, Mie University, Tsu. 
deficiency, (b) chronic riboflavin deficiency, $(c)$ acute anemia by venesection, and (d) chronic iron deficiency. In group $b$ and $d$, rats weighing $80-100 \mathrm{~g}$ were used with those of the same range of body weight as the control. In group $a$ and $c$ as well as in the control groups, the animals weighing about $150 \mathrm{~g}$ were used.

Acute Riboflavin-deficient Group - Rats were fed for 3-4 weeks with the riboflavin deficient diet. It is composed of, in $\mathrm{g}$ per $100 \mathrm{~g}$, riboflavin-free casein (NBC) 20.0, purified sugar 62.6, soy-bean oil 10, McCollum salt (No. 185) 4, DLmethionine 0.3 , choline chloride 0.1 , carboxymethylcellose 2 , sulfaguanidine 0.5 , glucose 0.5 ; in $\mu \mathrm{g}$ per $100 \mathrm{~g}$, thiamine 500 , pyridoxine 500 , cyanocobalamin $3, p$ aminobenzoic acid 10,000, calcium pantothenate 4,000, inositol 10,000, folic acid 200, nicotinamide $5,000, \mathrm{~K}_{4} 500$; tocopherol 1,000 ; and in I. U. per $100 \mathrm{~g}$, A 2,000 and $\mathrm{D}_{2} 200$. The diet was purchased from Tōa Nutrition Chemical Co. Ltd.

Chronic Riboflavin-deficient Group — According to Sakurai (13), riboflavin requirement in rats is $3-10 \mu \mathrm{g}$. So they were kept on the feed mentioned above and $2 \mu \mathrm{g}$ of riboflavin was injected in the abdomen every other day. After 60 days they were used as chronic riboflavin-deficient rats.

Acute Anemia Group by Venesection - The rats were placed in duralumin cages and fed on the Oriental solid feed. They were venesected every day by bleeding $1-1.5 \mathrm{ml}$ from the tail vein for successive ten days.

Chronic Iron-deficiency — The rats were placed in duralumin cages and fed on the diet containing polished wheat flour, kneaded with milk and $0.03 \% \alpha, \alpha^{\prime}$ dipyridyl. The latter inhibits the absorption of iron in the diet, but it takes too long time to cause anemia. Therefore, they were bled by $0.5 \mathrm{ml}$ from the tail twice a week. After 6-7 months they were used as the deficient group.

Confirmation of Deficiency — For confirmation of riboflavin deficiency the contents of riboflavin in the liver and that for anemia by venesection or iron deficiency iron levels in serum (16), erythrocyte counts, and hemoglobin values were determined. As shown in Table 1, the riboflavin contents in the liver were reduced to one-half of the control in both acute and chronic riboflavin deficiency.

TABLE 1

Findings in Rats

\begin{tabular}{|c|c|c|c|c|c|}
\hline Group & $\begin{array}{l}\text { Riboflavin } \\
\text { in liver }\end{array}$ & $\underset{\text { iron }}{\text { Serum }}$ & $\begin{array}{l}\text { Erythrocyte } \\
\text { count }\end{array}$ & $\underset{\text { content }}{\text { Hemoglobin }}$ & $\begin{array}{l}\text { Nonhemin } \\
\text { iron in liver }\end{array}$ \\
\hline & $\mu g / g$ & $\mu \mathrm{g} / 100 \mathrm{ml}$ & & per cent & $\mu g / g$ \\
\hline Acute riboflavin deficiency & $11.7 \pm 2.2$ & & & & \\
\hline Acute anemia by venesection & & $81.7 \pm 2.5$ & $\begin{array}{c}562 \pm 24 \\
(10)\end{array}$ & $\begin{array}{c}51.4 \pm 3.4 \\
(10)\end{array}$ & $22.1 \pm 2.8$ \\
\hline Control & $26.7 \pm \frac{ \pm}{(6)} 2.1$ & $241.6 \pm 25.9$ & $\begin{array}{c}970 \pm 36 \\
(10)\end{array}$ & $\begin{array}{c}100.4 \pm 1.5 \\
(10)\end{array}$ & $27.3 \pm 3.3$ \\
\hline Chronic riboflavin deficiency & $10.9 \pm 2.0$ & & & & $23.0 \pm 3.0$ \\
\hline Control & $19.0 \pm 1.7$ & & & & \\
\hline Chronic iron deficiency & $32.2 \pm 2.3$ & $87.0 \pm 2.7$ & $\begin{array}{c}701 \pm 48 \\
(12)\end{array}$ & $67.7 \pm 1.8$ & $9.8 \pm 2.1$ \\
\hline Control & $\begin{array}{l}32.2 \pm 2.1 \\
(18)\end{array}$ & $254.2 \pm 55.9$ & $\begin{array}{c}934 \pm 34 \\
(8)\end{array}$ & $98.8 \pm 2.1$ & \\
\hline
\end{tabular}

Parenthesized figures show the number of cases. 
Serum iron level, erythrocyte count and hemoglobin value fell markedly in acute anemia and chronic iron deficiency as compared with the control. Further, in a part of each group the level of non-hemin iron in the liver was examined, and in a part of chronic iron deficiency the contents of riboflavin in the liver were determined. As shown in Table 1, non-hemin iron was decreased definitely in chronic iron deficiency, but other groups did not show any marked change as compared with the control. The level of riboflavin in the liver did not fall in chronic iron deficiency. Thus it was confirmed that iron was not deficient but riboflavin was surely deficient in riboflavin-deficient group and that riboflavin was not deficient but the iron in both blood and tissues was decreased in chronic iron deficiency. In the acute venesection anemia group anemia was present but no decrease in tissue iron was confirmed. Riboflavin was measured by Yagi's method (15), serum iron by Barkan's method (16) and non-hemin iron in the tissues by Yoneyama and Konno's method (17).

2. Incorporation of $P^{32}$ into DNA of the Epitheliar Cell Nuclei of the Mucous Membrane of Small Intestine

Orthophosphate- $\mathrm{P}^{32}$ was dissolved in Ringer solution to which the standard solution for determination of phosphate (Daiichi Kagaku Co., Ltd.) was added as a carrier to make $0.01 M$ solution. This mixture containg the radioactivity of $100 \mu \mathrm{C}$ was injected intraperioneally in rats. After a certain time interval, the animal was killed and the small intestine was taken out. It was washed well with saline and was cut into a piece, about $10 \mathrm{~cm}$ in length. It was cut lengthwise and water was removed with a filter paper. The mucosa was scraped slightly with a sharp knife. The mucosa thus obtained contained all the villi and the majority of the crypts (18). The nuclei were isolated from the mucosa, DNA was extracted according to Davidson et al. (19) and the radioactivity incorporated was measured. A certain time after $\mathrm{P}^{32}$ injection, blood was withdrawn and the specific radioactivity of acid-soluble phosphorus was measured. Relative specific radio-activity was calculated by dividing the specific radioactivity of DNA- $\mathrm{P}^{32}$ by that of acid-soluble phosphorus.

Separation of Epithelial Cell Nuclei of the Small Intestinal Mucosa-Three milliliters of $0.05 \mathrm{M}$ citric acid solution was added to the mucosa and was homogenized by a glass homogenizer. After filtration with nylon gauze, the filtrate was centrifuged at $66 \times g$ for 10 minutes. The residue was washed with $0.01 \mathrm{M}$ citric acid by centrifugation at $375 \times g$ for 5 minutes. Repeated washing with the same acid solution by centrifuging with gradually less speed till the supernatant became transparent. The residue was washed twice with $10 \%$ trichloroacetic acid, once with acetone, once with ethanol, once with ethanol-chloroform $(3: 1)$, once with ethanol-ether $(3: 1)$ and finally once with ether and dried. By this treatment the lipids attached to the nuclear membrane was removed and no radioactivity was detected in the final washing.

Extraction of DNA from Nuclei-One milliliter of $0.05 \mathrm{~N} \mathrm{KOH}$ was added to the dried neclei per $100 \mathrm{mg}$. It was completely dissolved after being kept at $37^{\circ}$ for 24 hours. After adjusting the $\mathrm{pH}$ to 1 with $10 \mathrm{~N}$ perchloric acid, the whole was centrifuged. The residue was washed completely with $0.5 \mathrm{~N}$ perchloric acid, then with ethanol and ether and dried. No radioactivity was detected in the final 
washing. By these treatments inorganic phosphorus derived from phosphoproteins, RNA and nucleotide phosphorus were contained in the supernatant, whereas all the DNA phosphorus was contained in the precipitate. The precipitate thus obtained was dissolved in $5 \mathrm{ml}$ of $0.9 \%$ saline, and the $\mathrm{pH}$ was adjusted to 7 with $1 \mathrm{~N}$ $\mathrm{NaOH}$. Then $0.5 \mathrm{ml}$ of $0.5 \%$ sodium dodecyl sulfate in $45 \%$ ethanol (22) was added, followed by shaking for $2-4$ hours. Then after addition of $0.5 \mathrm{~g} \mathrm{NaCl}$, the whole was shaken vigorously, followed by centrifugation to remove denatured proteins. About twice as much 95\% ethanol was added to the supernatant and the whole was centrifuged to precipitate the sodium salt of DNA. It was washed well with $70 \%$ ethanol, absolute ethanol, acetone and ether successively and dried. No radioactivity was detected in the final washing.

Incineration of DNA Phosphorus - Sodium salt of DNA was placed in a micro-Kjeldahl flask. After addition of $1 \mathrm{ml}$ of $5 \mathrm{~N} \mathrm{H}_{2} \mathrm{SO}_{4}$ it was heated gradually till white smoke began to rise. It was then cooled and a drop of perchloric acid was added and heating was continued. If the black color persisted, another drop of the acid was added and heated again till the mixture became colorless and transparent. Throughout the operation care was taken that the white smoke did not get out of the flask (24). After the solution became colorless, it was heated further for one minute and cooled. By addition of a cerain amount of water followed by heating in a boiling water bath for 10 minutes, the pyrophosphoric acid produced in incineration was changed to orthophosphoric acid.

Determination of Phosphorus — Inorganic phosphorus produced by incineration was determined by Fiske and Subbarow's method (25).

Incineration of Acid-soluble Phosphorus in Blood and Determination of Phosphorus — To $1 \mathrm{ml}$ of blood was added $3 \mathrm{ml}$ of $10 \%$ trichloroacetic acid. The supernatatnt after centrifugation was heated in a micro-Kjeldahl flask and concentrated by heating to about $0.5 \mathrm{ml}$. Further treatment was the same as described above.

Measurement of the Radioactivity of $P^{32}$ A good quality filter paper was placed on the urea-resin dish (Chiyoda Hoanyohin Co., Ltd.) on which exactly $0.2 \mathrm{ml}$ of the incinerated DNA phosphorus or of the incinerated acid-soluble phosphorus of blood was added. After drying gradually in a desiccator, the radioactivity was measured for 1 minute by a Geiger-Müller Counter.

Relative Specific Radioactivity of DNA-P $P^{32}$ - The absolute amount of $\mathrm{P}^{32}$ incorporated into DNA can be estimated by multiphying the specific radioactivity of $\mathrm{P}^{32}$ in DNA by the amount of DNA. But the values fluctuate considerably since the amount of DNA is variable according to the portion of the tissue taken for determination. Therefore, according to Davidson et al. (19) the specific activity of the inorganic phosphorus in blood is taken as reference and the values of the specific activity of DNA-P ${ }^{32}$ divided by the former, relative specific activity, are used for the criterion of $\mathrm{P}^{32}$ incorporation into DNA. There was, however, a difficulty of using much blood for determinig the specific activity of inorganic phosphorus in blood. O'Dell et al. $(26,27)$ showed thereafter the usability of the specific activity of acid-soluble phosphorus in place of inorganic phosphorus. It has the advantage of using little blood. The authors have therefore adopted the latter method. It was calculated as follows: 
Relative specific activity $=$

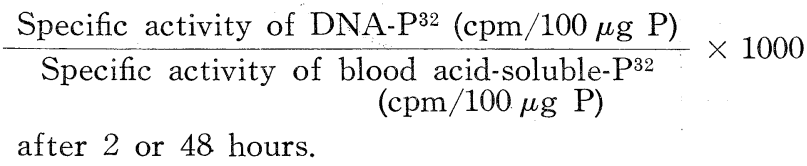

In chronic riboflavin deficiency the specific activity of blood acid-soluble phosphorus 2 hours after injection of $\mathrm{P}^{32}$ was used and in other cases it was difficult to take the blood because of anemia, so that the specific activity 48 hours after injection was used. As shown in Table 2, certain relationship exists between the two values, so that either value can be used as reference.

TABLE 2

Relative Specific Activity of DNA-P ${ }^{32}$ in Epitheliar Cells of Small Intestinal Mucosa in Rats 48 Hours after Orthophosphate-P $P^{32}$ Injection

A, the specific activity of DNA-P ${ }^{32}$ divided by the specific activity of blood acidsoluble phosphorus $2 \mathrm{hr}$ after injection; B, the specific activity of DNA-P ${ }^{32}$ divided by the specific activity of blood acid-soluble phosphorus $48 \mathrm{hr}$ after injection.

\begin{tabular}{cccc}
\hline $\begin{array}{c}\text { No. of } \\
\text { rats }\end{array}$ & $\mathrm{A}$ & $\mathrm{B}$ & $\mathrm{B} / \mathrm{A}$ \\
\cline { 2 - 4 } & $\times 1,000$ & $\times 1,000$ & \\
1 & 550 & 1,130 & 2.05 \\
2 & 610 & 1,230 & 2.01 \\
3 & 550 & 970 & 1.76 \\
4 & 600 & 1,210 & 2.01 \\
5 & 520 & 1,000 & 1.92 \\
6 & 610 & 1,140 & 1.87 \\
Average & & & $\mathbf{1 . 9 4}$ \\
\hline
\end{tabular}

\section{RESULTS}

\section{P32 Incorporation into DNA of the Epitheliar Cells of the Small Intestinal} Mucosa in Normal Rats

At first, $\mathrm{P}^{32}$ incorportion into DNA of the epitheliar cells of the small intestinal mucosa in normal rats was determined successively. Taking the specific activity of blood acid-soluble phosphorus 2 hours after $\mathrm{P}^{32}$ injection as reference, the relative specific activity of DNA-P ${ }^{32}$ in epitheliar cell nuclei of the small intestinal mucosa was determined successively. As shown in Fig. 1, the values increased with time, arriving at the peak about 48 hours after injection, falling gradually thereafter. In the epitheliar cells of the small intestinal mucosa, only the cells in crypts repeat division and proliferation (28), and the $\mathrm{P}^{32}$ injected is incorporated into these portions. It reaches then the tops of the villi, then the cells are desquamated and exfoliated. It is therefore assumed that the time required to reach the maximum agrees roughly with the time needed for complete replacement of all the epitheliar cells. The value of 48 hours obtained here lies between 1.4 days observed by Bertalanffy (2) and Lebrond (29) and 2.5 days by Quastler (28). It is therefore assumed to be almost appropriate. The rat was killed 48 hours after $\mathrm{P}^{32}$ injection and the incorporation of $\mathrm{P}^{32}$ into DNA in epitheliar cell nuclei of the small intestinal mucosa was examined, as it is considered that lower 


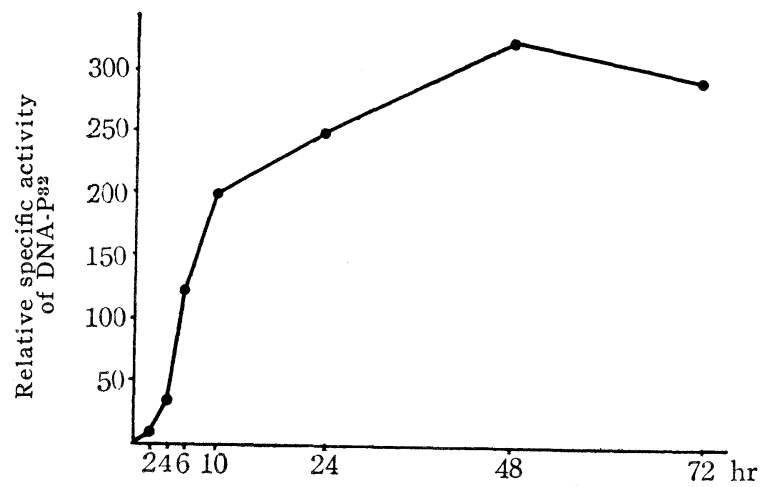

FIG. $1 \quad P^{32}$ Incorporation into DNA in Epitheliar Cells of Small Intestinal Mucosa of Normal Rats

The values divided by the specific activity of blood acid-soluble phosphorus $2 \mathrm{hr}$ after injection, $\times 1,000$. (Average of three estimations)

incorporation shows more inhibition of proliferation than higher one as far as the cell division does not become extremely rapid.

2. P2 Incorporation into DNA of Epitheliar Cell Nuclei of the Small Intestinal Mucosa in Acute Riboflavin Deficiency and Acute Anemia by Venesection in Rats

In three groups, acute riboflavin deficiency, acute anemia by venesection and

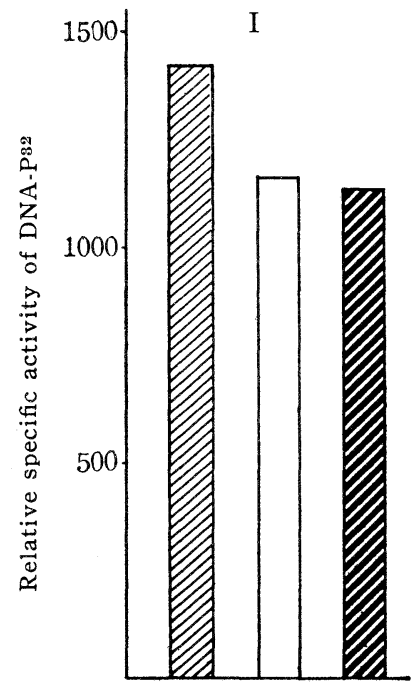

A

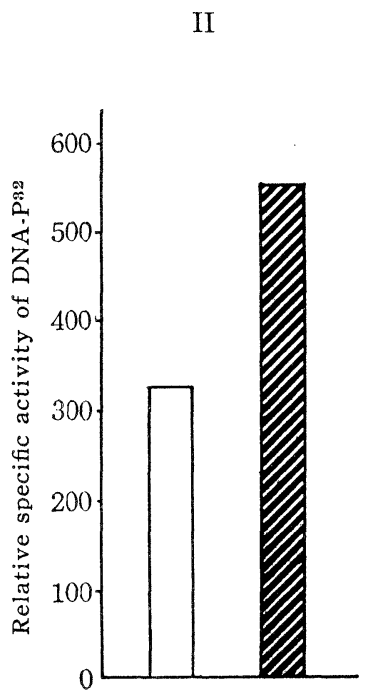

A

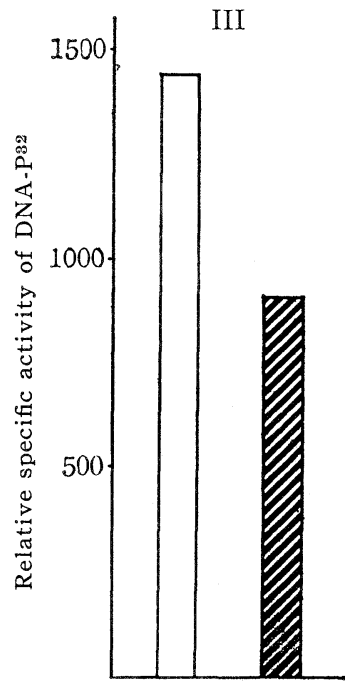

A $\mathrm{B}$

I. FIG. $2 P^{32}$ Incorporation into DNA in Epitheliar Cells of Small Intestinal Mucosa in Acute Riboflavin Deficient and Acute Anemia Rats (Average of 10 estimations in acute anemia and normal and of 6 cases in acute riboflavin deficiency)

A, acute anemia; B, normal; C, acute riboflavin deficiency. The values divided by the specific activity of blood acid-soluble phosphorus $48 \mathrm{hr}$ after injection, $\times 1,000$. 
II. FIG. $3 \quad P^{32}$ Incorporation into DNA in Epitheliar Cells of Small Intestinal Mucosa in Chronic Riboflavin Deficient and Normal Rats (Average of 5 cases in normal and of 6 cases in chronic riboflavin deficiency) The difference was significant $(p<0.05)$

A, normal; B, chronic riboflavin deficiency. The values divided by specific activity of blood acid-soluble phosphorus $2 \mathrm{hr}$ after injection, $\times 1,000$.

III. FIG. $4 \quad P^{32}$ Incorporation into DNA in Epitheliar Cells of Small Intestinal Mucosa in Chronic Iron Deficient and Normal Rats (Average of 8 cases of normal and of 12 cases of chronic iron deficiency)

A, normal; B, chronic iron deficiency. The values divided by blood acid-soluble phosphorus $48 \mathrm{hr}$ after injection, $\times 1,000$ The difference is significant $(p<0.10)$

the control common to both groups, $\mathrm{P}^{32}$ incorporation into DNA of the epitheliar cell unclei of the small intestine mucosa 48 hours after injection was examined. In acute riboflavin-deficient group, the incorporation was almost the same as in the control group but it increased significantly $(p<0.05)$ in the acute anemia group (Fig. 2).

3. P32 Incorporation into DNA of Epitheliar Cell Nuclei of the Small Intestine Mucosa in Chronic Riboflavin Deficiency

$\mathrm{P}^{32}$ incorporation into DNA of epitheliar cell nuclei of the small intestinal mucosa 48 hours after injection was examined, taking the specific activity of blood acid-soluble phosphorus 2 hours after injection as a reference. In chronic riboflavin-deficient group, the incorporation increased significantly $(p<0.05)$ as shown in Fig. 3.

4. P32 Incorporation into DNA of Epitheliar Cell Nuclei of the Small Intestine Mucosa in Chronic Iron Deficiency

Taking the specific activity of blood acid-soluble phosphorus 48 hours after $\mathrm{P}^{32}$ injection as a reference, $\mathrm{P}^{32}$ incorporation into DNA of epitheliar cell nuclei of the small intestinal mucosa was examined at the same time. As shown in Fig. 4, in chronic iron deficient group, the incorporation decreased significantly $(p<0.001)$.

\section{DISCUSSION}

There are many methods to examine the renewal rate of tissue cells. In this experiment, the $\mathrm{P}^{32}$ incorporation into DNA was examined. In cell division, DNA is preliminarily synthesized (30), so that the $\mathrm{P}^{32}$ injected is incorporated into DNA. Further it has been shown $(31,32)$ that the labelled phosphorus is not incorporated into the tissues in which the cell division does not take place. It is a method appropriate for examining the cell renewal rate.

The incorporation of the labelled phosphorus into the DNA of epitheliar cell nuclei of the small intestinal mucosa of rats was examined by the authors. It was shown that the incorporation increased remarkably in chronic riboflavin deficiency and did not decrease in acute riboflavin deficiency. Cell activity is naturally considered to be lowered in riboflavin deficiency but cell division was not only inhibited, but, on the contrary, it became more active in several cases. It seems to be contradictory but is also thought to be natural, considering that the proliferation 
of papillae is characteris tic for the change in the tongue, one of riboflavin deficiency symptoms. On the other hand, in chronic iron deficiency epitheliar cell division was definitely inhibited. It is therefore considered to be the characteristic of riboflavin deficiency that the epitheliar cell division is hardly inhibited. In acute anemia by venesection, the epitheliar cell division was promoted. It is possibly the appeareance of a temporary reaction of a living body for a sudden attack of venesection. In this group the serum iron level was decreased but not the level of iron in tissues, showing that the animals were not yet iron-deficient. Atrophy and hypertrophy are static states and they do not always correspond to the dynamic states of inhibition and stimulation of cell division. In both riboflavin and iron deficiencies the cells may be essentially in a state of atrophy, but in order to be manifest as atrophy some factors must be involved. However, based on the cell renewal rate, the following assumption might be possible. As it takes a certain time interval to get into atrophy, the probability of becoming atrophic may be greater in the inhibited state of cell divisions.

For examining the symptoms of mucosa, the study of the cell renewal rate is necessary, but no such study has yet been made. In this paper it was demonstrated that the cell renewal rate was not inhibited in chronic riboflavin deficiency, but was inhibited in chronic iron deficiency. The details of the appearance of mucosal symptoms (10) and of the intimate relationship of NADH-diaphorase and cell division (33) have been discussed by one of the authors.

\section{SUMMARY}

The cell renewal rate of small intestinal mucosa was examined, based on the $\mathrm{P}^{32}$ incorporation into DNA, in the groups of acute and chronic riboflavin deficiency, acute anemia by venesection and chronic iron deficiency in rats and the following findings were obtained.

1. In normal animals $\mathrm{P}^{32}$ incorporation into DNA in the epitheliar cells of the small intestinal mucosa arrived the maximal level about 48 hours after the injection, suggesting the complete replacement of the epitheliar cells of the mucosa in about 48 hours.

2. In both acute and chronic riboflavin deficiencies, the renewal rate of the epitheliar cells of the small intestinal mucosa did not decrease. In chronic riboflavin deficiency it was rather significantly increased.

3. The cell renewal rate was increased in acute anemia by venesection, whereas it was remarkably decreased in chronic iron deficiency.

\section{REFERENCES}

1. Sebrell, W. H., and Bulter, R.E., Publ. Health Rep. 53, 2282 (1938).

2. Bertalanffy, F. D., and Lau, C., Intern. Rev. Cytology. 13, 357 (1962).

3. Sevringhaus, E. L., and Kyhos, E. D., Arch. Int. Med. 76, 31 (1945).

4. Heilmyer, L., Lehrbuch der Inneren Medizin, Springer Velag, p. 385 (1957).

5. Darby, W. J., J. Amer. Med. Assoc. 130, 830 (1946).

6. Vannoti, A., Ciba Kagami, 3, 2 (1962).

7. Howell, J. T., and Monto, R. W., New Eng. J. Med. 249, 1009 (1953). 
8. Wintrobe, M. M., and Beebe, R. T., Medicine 12, 187 (1933).

9. Wynder, E. L., and Fryer, J.H., Ann. Int. Med. 49, 1106 (1958).

10. Miyaji, K., Vitamins 28, 347 (1963).

11. Blumenthal, C. M., A. M. A. Arch. Path. 33, 770 (1942).

12. Ebling, F. J., J. Erdocrinol 10, 147 (1954).

13. Sakurai, Y., Vitaminology (Japanese) ed. by Sahashi, K., Shimazono, N., Sakurai, Y., Nakagawa, I., Funabashi, S., Katsura, E., and Ogawa, S., Kanehara Shuppan K. K. Tokyo, p. $432(1956)$.

14. Lintzel, W., Biochem. Z. 263, 173 (1933).

15. Yagi, K., Biochemistry of Riboflavin (Japanese), p. 109 (1957).

16. Barkan, G., and Walker, B. S., J. Biol. Chem. 135, 37 (1940).

17. Yoneyama, M., and Konno, K., J. Biochem. 40, 377 (1953).

18. Miyaji, K., Abe, M., Watanabe, S., Ueno, H., Baba, K., and Kasho, A., Vitamins 25, 13 (1962).

19. Smellie, R.M.S., Humphrey, G.F., Kay, E.R.M., and Davidson, J. N., Biochem.J. 60, 177 (1955).

20. Mirsky, A.E., and Pollister, A. W., J. Gen. Physiol. 30, 117 (1947).

21. Egami, F., Nucleic acid and Nucleoprotein (Japanese). vol. II. p. 13 (1950).

22. Kay, E. R. M., Simons, N.S., and Dounce, A. L., J. Amer. Chem. Soc. 74, 1724 (1952).

23. Yoshikawa, H., and Takahashi, Y., Method of Phosphate Metabolism (Japanese). Hirokawa Shoten. Tokyo p. 39 (1958).

24. Hurukawa, Y., Taneda, M., Nakamura, K., Kasuga, S., and Yoshikawa, H., Biochemistry (Japanese) 24, 76 (1952).

25. Fiske, C. H., and Subbarow, Y., J. Biol. Chem. 81, 629 (1929).

26. O'Dell, B. L., and Bruemmer, J. H., J. Biol. Chem. 227, 737 (1957).

27. Daoust, R., Leblond, C. P., Nadler, N. J., and Enesco, M., J. Biol. Chem. 221, 727 (1956).

28. Quastler, H., and Sherman, F. G., Exptl. Cell Res. 17, 420 (1959).

29. Leblond, C. P., and Walker, B. E., Physiol. Rev. 36, 255 (1956).

30. Richards, B.M., Nature 175, 259 (1955).

31. Vendrely, R., and Vendrely, C., Experimentia 4, 434 (1948); 5, 327 (1949).

32. Boivian, A., Vendrely, R., and Vendrely, C., Compt. rend. Acad. Sci. 226, 1061 (1948).

33. Miyaji, K., Vitamins 27, 163 (1963). 